\title{
特集 —ーガスハイドレート研究の動向
}

\section{国産天然ガスとして研究開発が進む メタンハイドレートの二酸化炭素を用いた 増進回収法の概要}

Overview of Researches and Development about Enhanced Recovery Methods Using Carbon Dioxide for Methane Hydrate as Domestic Natural Gases

\section{池川 洋二郎}

Yojiro IKEGAWA

\begin{abstract}
The role of methane hydrate is discussed in demand situation of natural gases in Japan. Then, the necessity of methane hydrate enhanced recovery is shown in Japan project of methane hydrate. As one of the enhanced recovery methods, we are experimentally considering using carbon dioxide $\left(\mathrm{CO}_{2}\right)$. The latest results and its estimation show a possibility of using $\mathrm{CO}_{2}$.
\end{abstract}

[methane hydrate, carbon dioxide, enhanced recovery, natural gas, domestic product]

\section{1. はじめに}

本報告ではメタンハイドレートの役割を天然ガス の国内需要の状況に基づいて示した後, メタンハイ ドレートの経済的な生産技術が必要とされることか ら, 生産性や回収率を向上させる増進回収の検討状 況を示す。さらに当研究所が検討している増進回収 法に関する室内実験の結果と評価から二酸化炭素 $\left(\mathrm{CO}_{2}\right)$ が有効利用できる可能性を示す。

\section{2. わが国のエネルギー事情におけるメタンハイド レートの位置付け}

2014 年 6 月のエネルギー白書[1]には, 2011 年 3 月の東日本大震災以降, わが国の化石燃料の需要が 増加すると同時に, Fig. 1 に示すように天然ガス価 格が高騰し，米国や欧州との価格差が大きくなって いることが示されている。この天然ガスの需要増と 高騰による輸入額の増加は, わが国の貿易赤字の主 因[2]になっている。さらに, 2013 年初頭から 1 ド
ル 80 円程の為替レートが，100 円程の円安に転じ たことも貿易赤字の拡大要因となっている。また, 化石燃料の需要増は, 2010 年に $19.9 \%$ たっった一次 エネルギー自給率を 2012 年度には 6\%に低下させ, エネルギーの海外依存度が高くなっている。以上の 状況において, 液化天然ガス (LNG) 価格の低減 や一次エネルギー自給率の向上への対応策が望まれ る。現在, LNG は多様な地域の 10 方国程から石油 に連動した価格で輸入されており，2017 年には米 国国内の価格に連動するシェールガス起源の LNG の輸入が開始される予定で, LNG 価格の低減が期 待される。

化石然料は炭素 $\mathrm{C}$ と水素 $\mathrm{H}$ の化合物の炭化水素 を主成分とする有機物であるが，自然の存在状態の 違いで呼称が異なる。在来型の天然ガス, シェール ガス, メタンハイドレートの主成分はメタン $\left(\mathrm{CH}_{4}\right)$ で, 天然ガスとして利用される。在来型天然ガスの 自然の存在状態は, キャップロックと呼ばれる浸透 率の小さな泥岩が打椀を伏せたような馬の背状の背 斜構造下部の砂岩中に存在する。シェールガスは石 


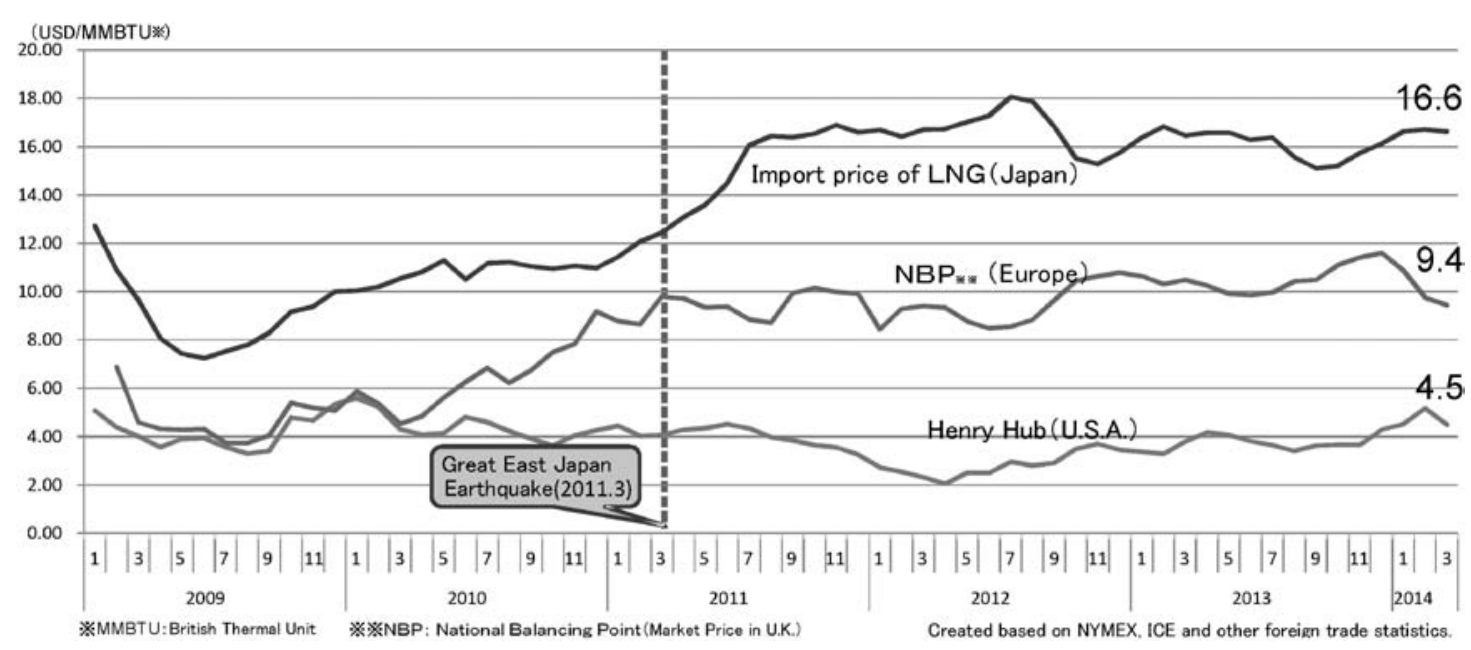

Fig. 1. Trends in LNG import price and price deference [1].

$※$ MMBTU is equivalent to about $25 \mathrm{~m}^{3}$ natural gas of normal temperature and pressure.

油の母岩とされる深度数千 $\mathrm{m}$ の有機質に富んだ頁 岩（泥岩）中に含まれるもので, 生産対象層を経済 的に水圧で破砕する技術開発により, 北米で商業生 産が始まっている。一方, 水圧破砕に利用する水に 含まれる化学物質による飲料水の污染が指摘され, 環境保全の対策が求められている。メタンハイド レートは, 主に永久凍土層の下部々深度 $500 \mathrm{~m}$ 以 深で, 温度が数 $10^{\circ} \mathrm{C}$ 以下の海底下地層に存在して いる。

さて, エネルギー基本計画 [3]に抢けるエネル ギー需給に関する長期的, 総合的かつ計画的に講ず べき施策の章では,「海洋に打けるエネルギー・鉱 物資源の開発ができれば, 自給率を飛躍的に高める ことができる可能性がある」とし，「メタンハイド レートに関して，2018年度を目途に商業化の実現 に向けた技術の整備を行う。その際, 2023 年から 2027 年の間に, 民間企業が主導する商業化のため のプロジェクトが開始されるよう, 国際情勢をにら みつつ技術開発を進める」と記載され, 他のエネル ギー資源に記載されていない明瞭な目標と時期が示 されている。経済産業省のメタンハイドレート開発 促進事業は 2000 年度に開始されているが，ここ数 年の天然ガスの情勢変化で, 国産エネルギーとして の重要性が増していると考えられる。

また，メタンハイドレートの商業化時期を左右す る国際情勢としては, 経済的に回收できない非在来 型資源とされていたシェールガスとシェールオイル が北米で商業化され, 生産が拡大していることが挙
げられる。米国の一次エネルギー自給率は向上し， 米国自身がエネルギー供給国に転じることで, 国際 的なエネルギー需給バランスが変化している。

他の国際情勢としては, 経済的に生産可能と推定 される確認可採埋蔵量と, これを年生産量で除した 可採年数は, 石油はそれぞれ 1.7 兆バレルで 53 年, 天然ガスは 184 兆 $\mathrm{m}^{3}$ で 56 年, 石炭は 8,609 億トン で 109 年と公表されるが, 経済発展が著しいブラジ ル，ロシア，インド，中国（BRICs）のエネルギー の需要増で, 2035 年には 2011 年比の 1.3 へ増加す る[1]と見込まれ, 需給バランスの変化による価格 の不安定化も懸念されている。

Fig. 1 の NBP（欧州）とヘンリーハブ（米国） は，地続きの大陸でパイプライン輸送される気体の 天然ガスの価格であるが，島国のわが国は液化天然 ガス（LNG）を船輸送するため，液化コスト $3 \sim 4$ ドル/MMBTU と, 米国から輸送する場合は輸送コ スト 3 ドル/MMBTU が含まれる $[1]$ 。ここに MMBTU は英国熱量単位で, 標準状態で約 $25 \mathrm{~m}^{3}$ である。液化や輸送コストを含む在来の LNG 価格 に対して, 国産メタンハイドレートが高い価格競争 力によって商業化された場合, シェールガスに続く 価格抑止力として機能することが期待される。

\section{3. メタンハイドレート資源の開発研究と増進回収 技術の研究状況}

これまで経済産業省の事業で開発研究が進められ 
てきた「砂層型」メタンハイドレートに加え, 主に 日本海側で確認されている「表層型」メタンハイド レートが 2013 年度からの計画に新たに位置づけら れている。表層型は資源量把握のために 2013 年度 から 3 年程で, 広域的な分布調査が計画され, 2013 年度の上越沖及び能登半島西方沖合での調查で, メ タンハイドレートが存在する可能性がある地層構造 が確認されている。その後の調査の結果を踏まえ, 資源回収技術の本格的調査や研究開発等が着手され る $[1]$ 。

砂層型は東部南海トラフ海域で, わが国の天然ガ 又消費量の約 10 年分の原始資源量が推定され, 2013 年 3 月に海域に抢ける減圧法によってガス生 産が世界で初めて確認されている。これらの成果を

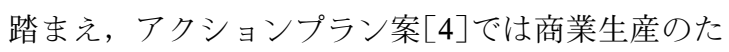
めに実現すべき内容として(1)長期・安定的なガス生 産, (2)生産コストの低減, (3)環境に配慮した生産シ ステムが提示され, 克服すべき具体的な技術課題が 示されている。また, 海洋基本計画 $[5]$ に対応する ように 2018 年度を目途に, 商業化の実現に向けた 技術の整備が示され，陸上および海洋上での中長期 の産出試験計画が示されている。

メタンハイドレートは, 水分子の水素結合によっ て形成される正 12 面体や 14 面体などの籠状格子に, メタン分子 $\left(\mathrm{CH}_{4}\right)$ がトラップされた包接水和物 (clathrate hydrate) である。また, 固体で自噴しな いため, 地層内で加熱, 減圧, 及びこれらの組合せ で, 水とガスに分解して生産する方法が検討されて いる。上述の海域でガス生産が確認された減圧法で は, 層厚が $100 \mathrm{~m}$ 弱のメタンハイドレート生産対 象層に設けた井戸から水を汲み上げることで，10 数 MPa の地下水圧を数 MPa に低減し, 水とガス に分解している。

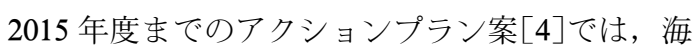
域等での中長期の生産試験と並行して, 砂層型メタ ンハイドレートの生産コストを低減させる技術とし て増進回収法が検討されている。増進回収は, 石油 では商業利用され, 回収率や生産性を向上させるこ とで生産コストを低減する技術である。地層中の水 より石油の密度は小さく, 水に押されるように自噴 するが, 粘性が高い石油成分は地層中に残るため, 回収率は 10 20\%程と言われる。そこで注入井か ら油層に水/海水を注入し, 追い出すように回収率 を上げる水攻法が行われている。さらに $\mathrm{CO}_{2}$ を用 いる石油の増進回収法 $\left(\mathrm{CO}_{2}\right.$-EOR $)$ も 1970 年代か
ら米国で商業化されている。この $\mathrm{CO}_{2}$-EOR では, $50^{\circ} \mathrm{C}$ 程の油層に注入した $\mathrm{CO}_{2}$ が超臨界となり, 地 層中の原油と混合した状態となって粘性が低下する ことから, 複数の注入井と生産井の間で $\mathrm{CO}_{2}$ を循 環させることで石油の回収率を上げている。

しかし, 砂層型メタンハイドレートが存在する地 層温度は 10 数 ${ }^{\circ} \mathrm{C}$ 以下で, 深度相当の水圧を考える と $\mathrm{CO}_{2}$ は液体なので, 超臨界の特性が利用できな い。このため対象地層中に抢ける $\mathrm{CO}_{2}$ の物理化学 的特性を利用した新しい増進回収が研究されている。 独立行政法人石油天然ガス・金属鉱物資源機構は, 米国エネルギー省の補助金を利用した共同研究で

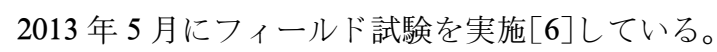
この方法では $\mathrm{CO}_{2}$ と窒素 $\left(\mathrm{N}_{2}\right)$ の混合ガスを地層 中に注入し, メタン分子より $\mathrm{CO}_{2}$ 分子がハイド レート格子にトラップされやすい性質を利用するゲ スト分子置換法 [7]が適用されている。高純度の $\mathrm{CO}_{2}$ を注入した場合, 地層中に $\mathrm{CO}_{2}$ ハイドレート が生成して孔隙が閉塞することで $\mathrm{CO}_{2}$ が注入でき なくなるため， $\mathrm{N}_{2}$ を混合して $\mathrm{CO}_{2}$ 分圧を下げ， $\mathrm{CO}_{2}$ ハイドレートが生成しない条件にしている。

また, 独立行政法人産業技術総合研究所は, 生産 対象層の地下水圧を $2.56 \mathrm{MPa}$ 以下に減圧すること で, 地層内に生じる氷の生成熱を利用して増進回収 を行う強減圧法に関し, 世界最大とされる高さ $3.2 \mathrm{~m}$, 外径 $1.4 \mathrm{~m}$, 設計圧力 $16 \mathrm{MPa}$ の圧力容器を 用いた大型実験とシミュレーションによる検証で, 増進回収の効果を確認 $[8]$ してい。

\section{4. $\mathrm{CO}_{2}$ ハイドレートの生成熱を利用する増進回 収法の現業成果と考察}

当研究所は, $\mathrm{CO}_{2}$ と水を微細に混合したエマル ションを地層中に注入し, $\mathrm{CO}_{2}$ ハイドレートを均 質に生成させ, $\mathrm{CO}_{2}$ ハイドレートが相平衡となる 温度に加温することで閉塞回避する方法を提案し, 室内の実験検証 $[9,10]$ を進めている。ここで利用す るエマルションは, 注入対象層の孔隙より小さい, 直径 $10 \mu \mathrm{m}$ 程の $\mathrm{CO}_{2}$ 液滴が水中に多数浮遊する状 態である。

Fig. 2 は $\mathrm{CO}_{2}$ ハイドレートの温度-圧力相図にメ タンハイドレートの相図を重ね合せた図を示す。2 つの相図の重なりから，10 数 ${ }^{\circ} \mathrm{C}$ 以下の地層では $\mathrm{CO}_{2}$ を利用した増進回収の検討が可能であると考 えている。今後は $\mathrm{CO}_{2}$ とメタンの混合ガスの場合 


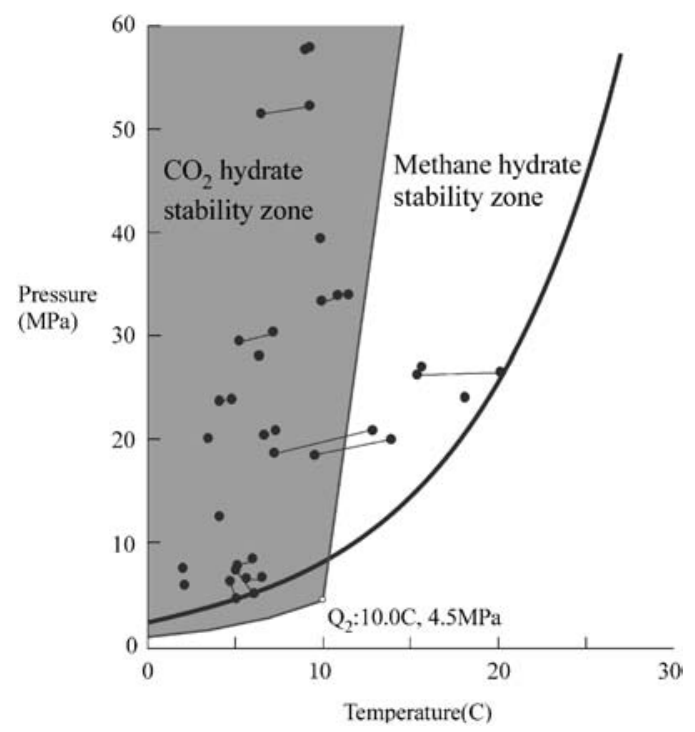

Fig. 2. Temperature-pressure phase diagram of $\mathrm{CO}_{2}$ hydrate super imposed on the phase diagram of methane hydrate. Filled circles are properties of methane hydrate at the individual discovery points and lines between circles are range of the properties.

の課題に関する取組みが必要である。

Table 1 は想定する $\mathrm{CO}_{2} /$ 水エマルションの 注入条件を示し, 年間のエマルション注入量は $3,000,000 \mathrm{~m}^{3}$, 注入対象の海底下の円柱状領域の半 径は約 $200 \mathrm{~m}$ である。また, 対象層は層厚 $10 \mathrm{~cm}$ 程で, 砂層と泥層が水平に積層したものを想定し, 砂層の孔隙部分にエマルションを注入し, $\mathrm{CO}_{2}$ 八 イドレートの生成熱で円柱状領域を $3^{\circ} \mathrm{C}$ 程度加温す ることを目的としている。ここに $3^{\circ} \mathrm{C}$ は国のシミュ レーションで増進回収が見込まれる温度上昇に相当 する。

Fig. 3 は実験装置の模式図で, 長さ 1,500 mm の 圧力セル内に水で飽和させた 7 号硅砂に拘束圧を作 用させている。温度は $50 \mathrm{~mm}$ 間隔で設置した熱電 対で砂表面を計測した。また, エマルションは $\mathrm{CO}_{2}$ と水をセットしたシリンジポンプから一定流 量で送り, 途中のミキサーで混合してエマルション にして圧力セル内に浸透させた。また，模擬砂層の 孔隙圧は下流側のシリンジポンプで一定制御した。 エマルションの浸透速度は, Table 1 の条件に抢い て注入坑井から $2 \mathrm{~m} \sim 4 \mathrm{~m}$ の距離に生じる流速を利 用した。

Fig. 4 は実験結果の一例を示し, Fig. 4a は Fig. 3
Table 1. Injection volume of assumed emulsion.

\begin{tabular}{|c|c|}
\hline & Unit \\
\hline \multirow[t]{2}{*}{$\begin{array}{l}\text { Injection volume of } \mathrm{CO}_{2} / \text { water } \\
\text { emulsion }\end{array}$} & $3,000,000 \mathrm{~m}^{3}$ year $^{-1}$ \\
\hline & $0.095 \mathrm{~cm}^{3} \mathrm{sec}^{-1}$ \\
\hline $\mathrm{CO}_{2}$ & $50 \mathrm{vol} \%-\mathrm{CO}_{2}$ \\
\hline The height of layers & $100 \mathrm{M}$ \\
\hline Ratio of sand layers & 0.5 \\
\hline $\begin{array}{l}\text { The height of sand layers } \\
\qquad(4)=(2) \times(3)\end{array}$ & $50 \mathrm{M}$ \\
\hline Injection ratio & $1902.6 \mathrm{~cm}^{3} \mathrm{sec}^{-1} \mathrm{~m}-\mathrm{sand}^{-1}$ \\
\hline Porosity of the sand layers & $50 \%$ \\
\hline $\begin{array}{l}\text { Volume of the cylindrical layers } \\
\qquad(6)=(1) /(3) /(5)\end{array}$ & $12,000,000 \mathrm{~m}^{3}$ \\
\hline $\begin{array}{l}\text { Radius of the cylindrical layer } \\
\qquad\{(6) /(2) / \pi\}^{1 / 2}\end{array}$ & $195.5 \mathrm{~m}$ \\
\hline
\end{tabular}

の水槽下部の水と外筒の温度が，それぞれ $10^{\circ} \mathrm{C}$ と $7^{\circ} \mathrm{C}$ で一定であることを示す。Fig. $4 \mathrm{~b}$ と Fig. $4 \mathrm{c}$ で は拘束圧は $9.5 \mathrm{MPa}$ ，孔隙圧は $8.5 \mathrm{MPa}$ と一定で あることを示すが，経過時間 180 分の所で孔隙圧が 上昇していることから閉塞が生じている。Fig. $4 \mathrm{~d}$ はシリンジポンプで計測された流量を示し, 経過時 間 20 分の所で圧力セルの上流部にエマルションを 浸透させた後, 約 90 分間, $7^{\circ} \mathrm{C}$ に維持することで $\mathrm{CO}_{2}$ ハイドレートを生成させた。その後, 圧力セ ルを $7^{\circ} \mathrm{C}$ 冷却することを停止した後にエマルション を $4 \mathrm{~cm}^{3} \mathrm{~min}^{-1}$ で浸透させた。Fig. $4 \mathrm{e}$ は熱電対の温 度変化を示し, 浸透の上流側の熱電対から温度が順 次 $7^{\circ} \mathrm{C}$ から, $\mathrm{CO}_{2}$ が相平衡となる $10^{\circ} \mathrm{C}$ に温度上昇 していることが分かる。これらの手順は, 陸上や海 洋の生産試験で実施できると思われる手順を考慮し たものである。

以上の結果を考察すると，まず，浸透によって下 流側に移動していくエマルションの浸透先端で, $\mathrm{CO}_{2}$ ハイドレートが生成し, $\mathrm{CO}_{2}$ ハイドレートが 相平衡となる約 $10^{\circ} \mathrm{C}$ に温度が上昇する。この時, 上流側のエマルションは, $\mathrm{CO}_{2}$ ハイドレートが相 平衡となった $10^{\circ} \mathrm{C}$ の砂層を浸透していると言える。 国のシミュレーションでは, 初期温度が数 ${ }^{\circ} \mathrm{C}$ 高い ことで生産性と回収率が向上することが示されて打 り, 増進効果が得られる温度上昇であると考えてい る。

また, 高純度の $\mathrm{CO}_{2}$ を浸透させた場合には, 温 


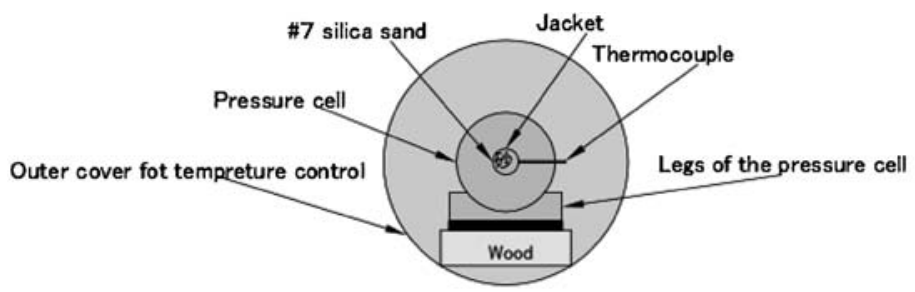

(a)Vertical cross-sectional view of the pressure cell

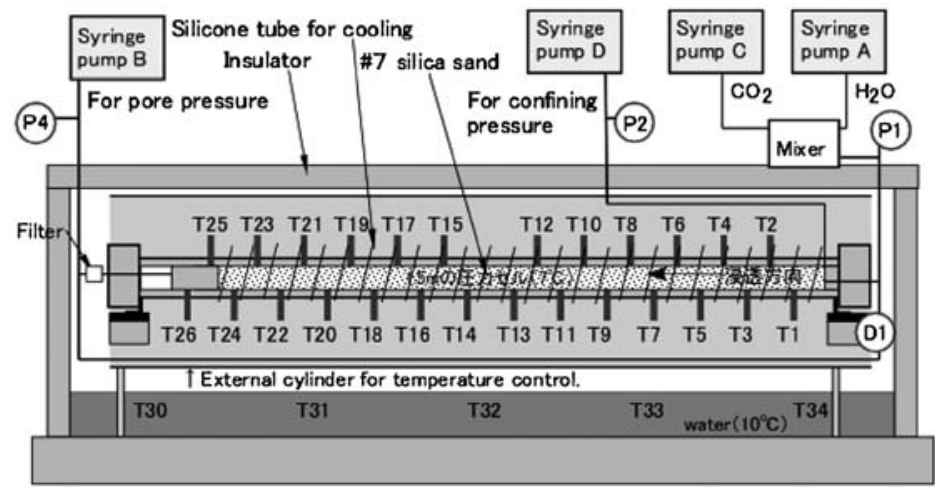

(b)Flow diagram and liactions of the sensors

Fig. 3. Schematic diagram of the experimental apparatus. The circumstances of layered sediments under the seabed are simulated in $1.5 \mathrm{~m}$ long horizontal pressure cell. The water pressure, stress of the silica sand and fluid flow in the sand pore are controlled by the syringe pumps. The temperature is controlled by using the external cylinder with temperature adjusted water. The change of temperature by exothermic heat of $\mathrm{CO}_{2}$ hydrate formation is measured by the thermocouples set to contact to the surface of the sand through the pressure cell.

度変化が得られることなく閉塞が生じる現象が生じ るのに対して，エマルションを利用することで，発 熱しながら浸透する挙動が示された結果は重要であ り，大きな技術的な進展が得られていると考えてい る。

一方, $\mathrm{CO}_{2}$ ハイドレートの生成によって最終的 に閉塞が生じた原因は, 対象層の条件から計算され る相平衡に至るまでの単位当たりの熱量に対して, 模擬実験では相平衡に至るまでに必要な熱量が大き く, 多くの $\mathrm{CO}_{2}$ ハイドレートが生成しているため である。まず, Table 1 で砂層と泥層の比熱容量の 比は $1: 1$ 程度に対して, 実験では泥層の熱容量に 相当する Fig. 3 の圧力セルは肉厚で $1: 9$ 程度 [10] である。次に，エマルションを浸透させる砂層を初 期温度 $7^{\circ} \mathrm{C}$ に維持することを目的に, 外筒を $7^{\circ} \mathrm{C} に$ 維持しているため, $7{ }^{\circ} \mathrm{C}$ と $10^{\circ} \mathrm{C}$ の間に生じる熱放 射によって, $\mathrm{CO}_{2}$ ハイドレートの生成熱が移動し ている。また，Fig. 4 で T11 以降の温度上昇が止ま っていることから上流側で $\mathrm{CO}_{2}$ が消費されている
とすると，T11 より上流側が閉塞していると考えら れる。これは先述の熱移動の考察から閉塞する可能 性が高い箇所と一致している。

Table 1 に示した層厚 $100 \mathrm{~m}$ 程の地層を対象にし た時, 対象層の上下端には温度勾配による熱移動が 生じることで閉塞しやすい条件となる。一方，上下 端を除く中央部は均質に相平衡 $\left(10^{\circ} \mathrm{C}\right)$ になると考 えられ，基本的に上下方向の温度勾配による熱移動 は生じないことから， $\mathrm{CO}_{2}$ ハイドレートの生成熱 で十分に相平衡となることから閉塞しないと考えて いる。

先述のゲスト分子置換法で $\mathrm{N}_{2}$ の確保に深冷法を 利用する場合，エネルギー投入が大きくなるのに対 し, 海洋で入手しやすい水/海水を利用すれば，工 ネルギー効率が高い増進回収法が検討できる。また, 相平衡を利用してエマルションを広範囲の生産対象 層に注入できた場合, 地層の加温による増進回収に 加え, 二次的にゲスト分子置換が生じて, さらに増 進回収率が向上すると思われる。 
导 16

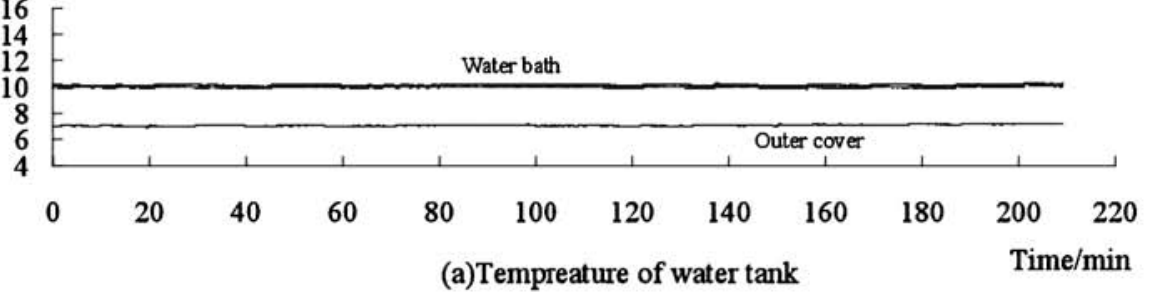

(a)Tempreature of water tank

Time/min
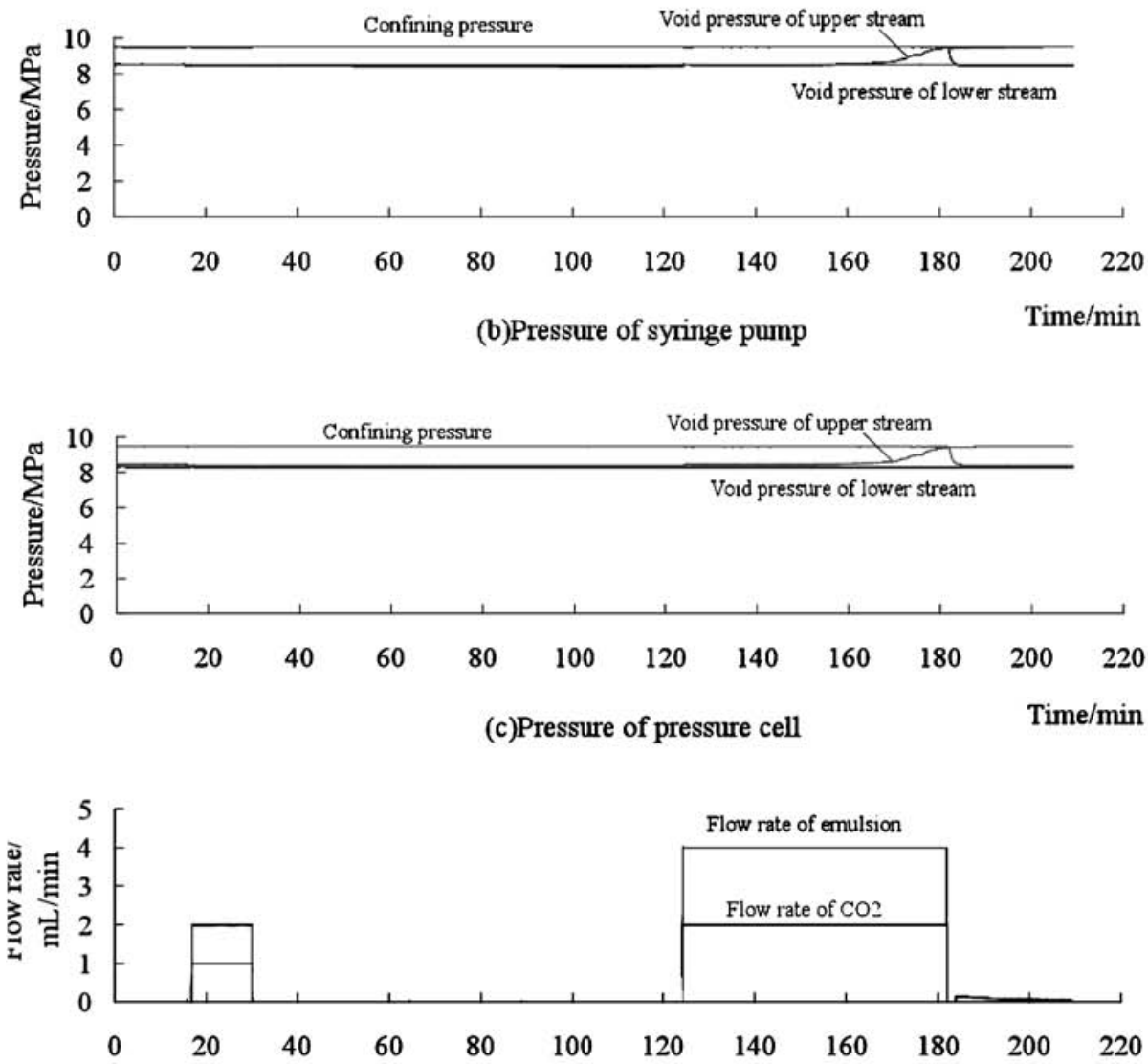

(d)Flow rate of syringe pump

Time/min

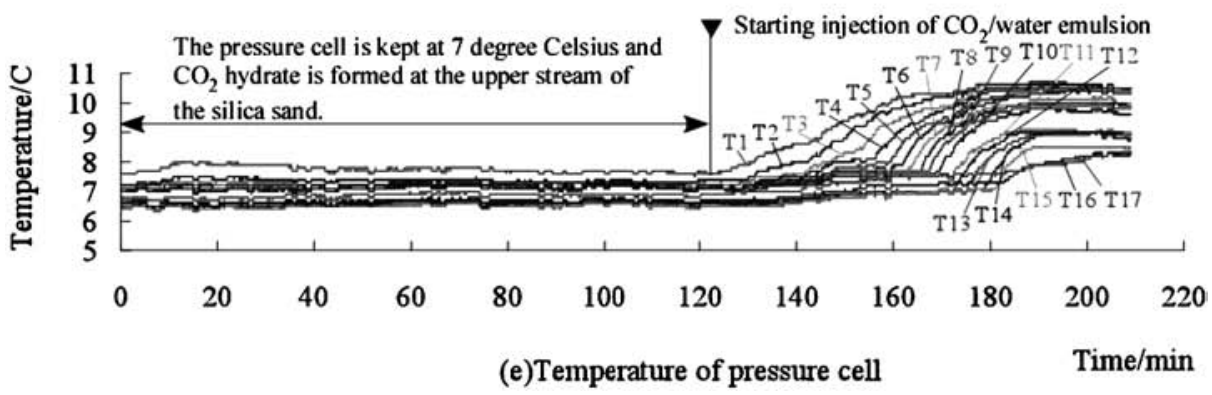

Fig. 4. Experimental data of temperature rise by $\mathrm{CO}_{2} /$ water emulsion flow though silica sand. 
今後は, 実験装置を実際の地層に生じる熱の条件 に近づける改良を進め, 多くの方々に納得いただけ る実験データの提示と評価に取り組みたい。

\section{5. おわりに}

本報告では, わが国の天然ガスの需要に関する最 新状況に対して, 国産天然ガスとして期待されるメ タンハイドレートに価格競争力が生じるような増進 回収法の研究により, 商業可能性が向上し, 輸入 LNG に対する価格抑止力が働くことで, 最終的に わが国が有利な天然ガスを利用できる環境に繋がる と考えている。

また，メタンハイドレートの経済的な生産に，い くつかの増進回収法が検討されているが, 当研究所 が取組んでいる $\mathrm{CO}_{2}$ を利用する方法に関して, 最 新の実験データと考察を示した。実験装置は改善途 上であるが，装置改良を継続し，信頼性の高いデー タに基づく評価によって, $\mathrm{CO}_{2}$ の有効利用法を将 来に繋がれることを願う。

\section{謝 辞}

二酸化炭素を用いる増進回収法に関する室内実験 のデータは, 経済産業省のメタンハイドレート開発 促進事業で進められているメタンハイドレート資源 開発研究コンソーシアム（MH21）の生産手法開発 グループの研究の一部として得られた成果を利用さ
せていただきました。ここに関係の方々に深く謝意 を表します。

\section{参考文献}

［1］経済産業省 資源エネルギー庁：平成 25 年度エ ネルギーに関する年次報告（エネルギー白書 2014） (経済産業省，2014）。

[2] 財務省: 平成 25 年 11 月中国際収支状況 (速報) の概要 (財務省, 2014).

［3］経済産業省 資源エネルギー庁：エネルギー基 本計画（経済産業省，2014）.

［4］経済産業省：メタンハイドレート開発実施検討 会（第 27 回）, 資料 6-1, 平成 27 年度までのアク ションプラン案について（経済産業省, 2014).

［5］首相官邸総合海洋政策本部：海洋基本計画 （首相官邸，2013）。

[6] 独立行政法人 石油天然ガス・金属鉱物資源機 構: 二ュースリリース 2012 年 5 月 2 日（石油天然 ガス・金属鉱物資源機構，2012）。

[7] K. Ohgaki, K. Takano, H. Sangawa, T. Matsubara, S. Nakano: J. Chem. Eng. Jpn., 29, 478 (1996).

[8] 今野義浩, 神裕介, 長尾二郎：第 5 回メタン八 イドレート総合シンポジウム講演集, A-12, pp. 54-55 (2013).

［9］池川洋二郎, 宮川公雄, 鈴木浩一, 窪田健二： 土木学会論文集, 67, 213 (2011).

[10］池川洋二郎, 宮川公雄, 鈴木浩一, 田中姿郎, 窪田健二：土木学会論文集，68, 172 (2012).

[2014 年 8 月 21 日受付, 2014 年 9 月 3 日受理] (C) 2014 日本高圧力学会 